\title{
Fabrication of computer-aided design/computer-aided manufacturing complete denture and conventional complete denture: case report
}

\author{
Mi-Jin Kim, Kang-Ho Kim, Dong-Heon Yeo* \\ Department of Prosthodontics, Sahmyook Adventist Dental Hospital, Seoul, Republic of Korea
}

\begin{abstract}
Recently computer-aided technology has been widely used in dentistry. DENTCA ${ }^{\mathrm{TM}}$ CAD/CAM denture system (DENTCA Inc.), one of CAD/CAM systems for fabricating complete denture, tries to collect and store all of a patient's information at the first visit. This system aims to deliver denture at the second visit through utilizing the CAD/CAM software to access the stored data for designing the 3D denture model. The 3 dimensional (3D) denture will then be fabricated with 3D printer. Many case reports have evaluated clinical application of CAD/CAM system for fabricating complete dentures. This case report is about fabricating of complete dentures using DENTCA system and conventional method in same patient. With two cases, usefulness and limitation of DENTCA system could be evaluated. (J Dent Rehabil Appl Sci 2016;32(2):141-8)
\end{abstract}

Key words: computer-aided design/computer-aided manufacturing (CAD/CAM); complete denture

\begin{abstract}
서론
임플란트를 이용한 치료 범위의 확대로 고정성 보철 치료를 받을 수 있는 환자의 폭은 늘어났지만, 평균 수 명이 연장됨에 따라 의치 제작에 대한 수요는 여전히 계 속되고 있다 ${ }^{1}$.

의치 제작은 전통적 방법을 따를 경우에 최종 의치의 장착까지 여러 단계를 거쳐야 하며 환자의 잦은 내원과 그에 따른 비용의 증가가 불가피하다. ${ }^{2}$ 또한 의치의 파 절이나 분실 시 빠른 제작의 어려움이 발생한다. ${ }^{3}$ 이와 같은 기존 방법의 단점에도 불구하고 획기적인 방법의 부재로 70 년이 넘는 기간 동안 의치 제작의 방법에는 큰 변화가 없었다. ${ }^{4,5}$

하지만 최근에 치과에서 널리 이용되는 computeraided design/computer-aided manufacturing (CAD/ CAM) system ${ }^{6}$ 은 기존 의치 제작의 단점을 보완할 수 있
\end{abstract}

는 새로운 방법으로 기대되고 있다. 현재 미국에서 상용 화 되어있는 CAD/CAM 의치 시스템에는 $\mathrm{AvaDent}^{\mathrm{TM}}$ digital denture (Global Dental Science LLC, Scottsdale, $\mathrm{USA}$ )와 $\mathrm{DENTCA}^{\mathrm{TM}} \mathrm{CAD} / \mathrm{CAM}$ denture (DENTCA Inc. Los Angeles, USA)가 있으며 의치 제작 방법에 서 차이를 보인다. AvaDent는 미리 중합된 의치상 을 밀링하여 치아를 접착하는 방식이며, DENTCA는 stereolithography를 이용하여 try-in denture를 프린팅 하고 이것을 매몰하여 최종 의치로 변환시킨다. ${ }^{7}$

이미 여러 증례를 통해 CAD/CAM denture의 임상적 적용은 알려져 있으나 ${ }^{7,8}$ 국내에서, 전통적인 방법의 의 치와 동시에 제작하여 살펴본 증례는 없었다. 상-하 완 전 무치악 환자에서 DENTCA system과 전통적인 방법 을 사용하여 동시에 두 쌍의 총의치를 제작하고 살펴본 2 증례가 있어 이를 보고하고자 한다. 


\section{증례 보고}

\section{1. 증례 1}

75세의 남자 환자로 상, 하악 의치 제작을 주소로 내 원하였으며 2014년 폐암 발병 후 치료는 완료된 상태였 다. 2009년 본원에 내원 당시 상악은 무치악, 하악은 양 측으로 제 1,2 소구치만 잔존하고 있었으며 임시 의치 장 착 후 치료를 중단하였다. 2015년 7월, 하악 임시의치 지 대치의 파절로 다시 본원에 내원하였으며 상, 하악 무치 악 부위의 수복을 원하여 잔존 치근의 발치 후 임시 총 의치를 장착하였다. 2 달간 임시 의치를 사용 후 전통적 인 방법과 DENTCA system을 이용한 총의치를 제작하 였다. 먼저 전통적인 방법의 총의치 제작을 위해 첫 날 에 비가역성 하이드로 콜로이드 인상재(Aroma Fine ${ }^{\circledR}$ Plus, GC, Tokyo, Japan)로 예비인상을 채득 하였다. 자 가중합형 레진 $\left(\mathrm{Ostron} 100^{\circledR}, \mathrm{GC}\right)$ 으로 개인 트레이를 제 작하여 둘 째날에 모델링 컴파운드(Peri compound ${ }^{\circledR}$,
GC)로 변연을 형성하고 polyvinyl siloxane silicon 인상 재(Examixfine ${ }^{\circledR}$ regular type, GC)로 최종인상을 채득 하였다. 세 번째 날에 기록상과 교합제를 이용하여 중심 위를 기록하였고 네 번째 날에 납의치 시적을 거쳐 다섯 번째 날에 최종 의치를 완성하였다.

동시에 DENTCA system을 이용한 의치 제작도 함 께 진행하였다. DENTCA에서 제공하는 4가지 크기 의 기성 트레이 중 medium size의 트레이를 선택하여 hydrophilic polyvinyl siloxane silicon tray type의 인상 재(Exahiflex $\left.{ }^{\circledR}, \mathrm{GC}\right)$ 로 1차 인상을 채득하였다. 트레이 가 드러난 부분은 denture bur로 삭제하고 인상재를 추 가한 후 통상적인 근육운동을 시행하여 변연을 형성하 였다. 흐름성이 좋은 polyvinyl siloxane silicon 인상재 (Examixfine ${ }^{\circledR}$ regular type, GC)를 사용하여 최종인상을 채득하였다(Fig. 1). 트레이가 분리되는 부분에 \#15 블 레이드를 깊게 삽입하여 블레이드 끝으로 트레이의 접 촉을 확인하며 인상체를 잘라 전방부와 후방부를 분리 하였다(Fig. 2).
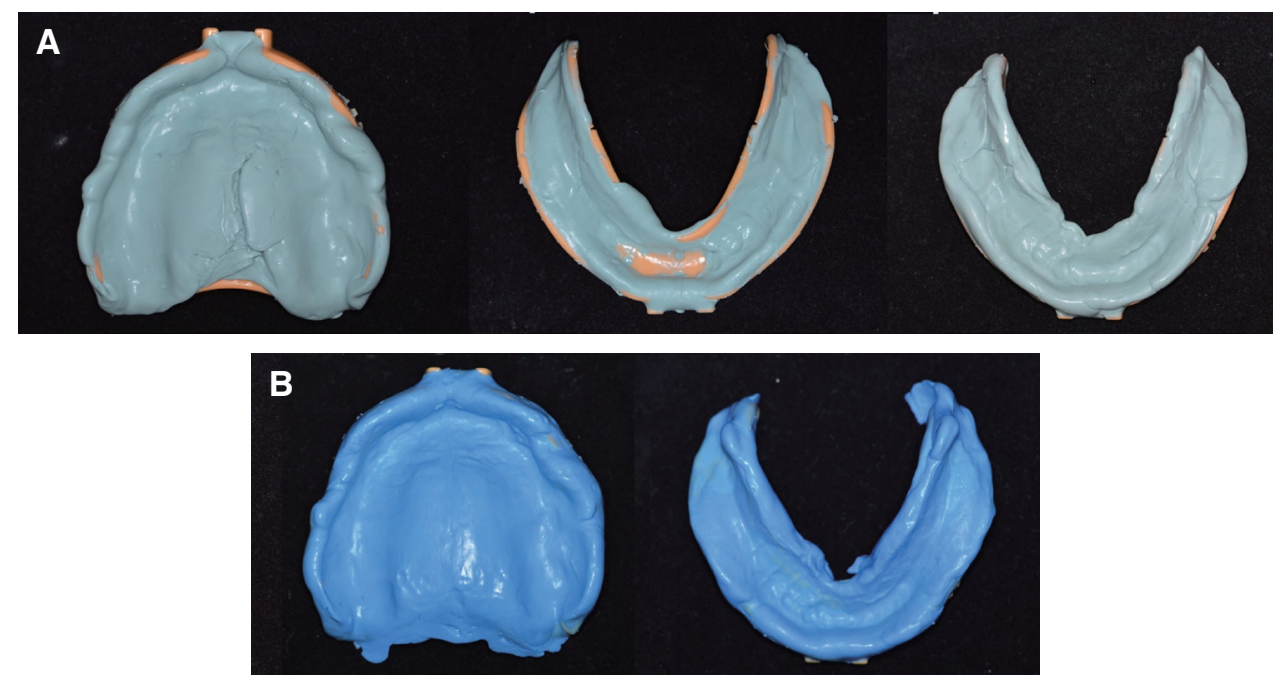

Fig. 1. (A) Maxillary and Mandibular first impressions, (B) Maxillary and mandibular definitive impressions.

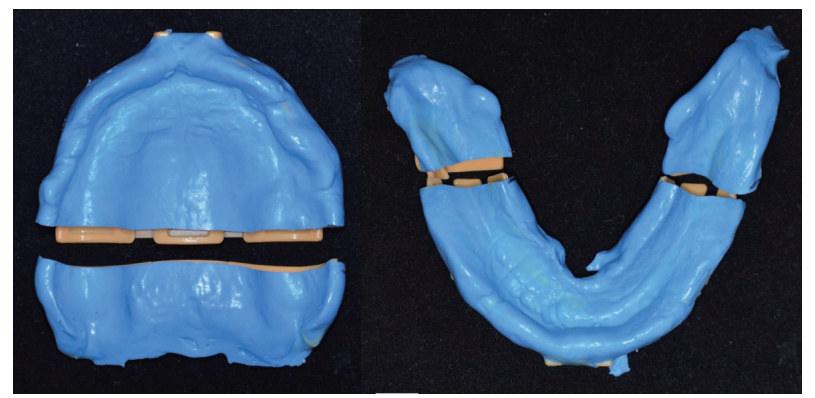

Fig. 2. Separated maxillary and mandibular definitive impressions with No.15 scalpel. 

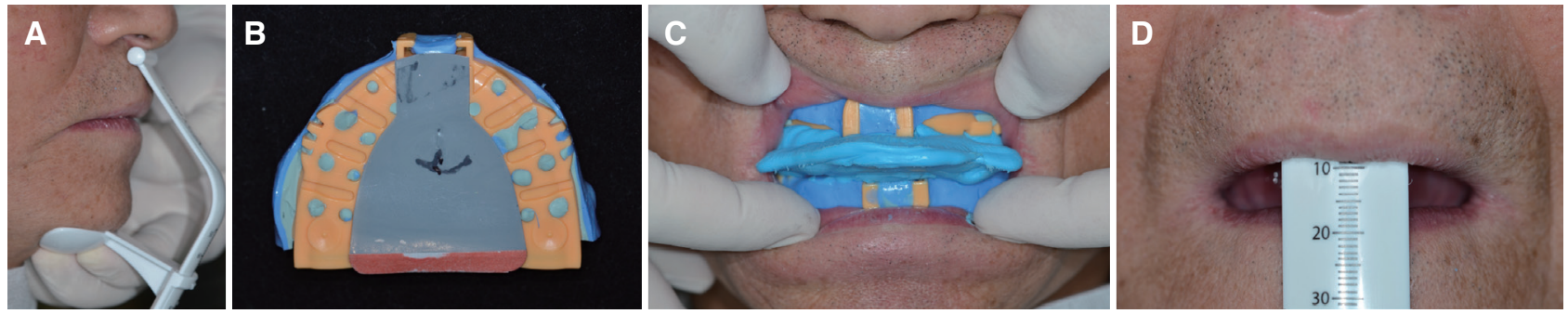

Fig. 3. (A) Jaw gauge used to determine the vertical dimension, (B) Gothic-arch tracing with the EZ-tracer, (C) Jaw relation recording, (D) Lip ruler used to measure length of upper lip.
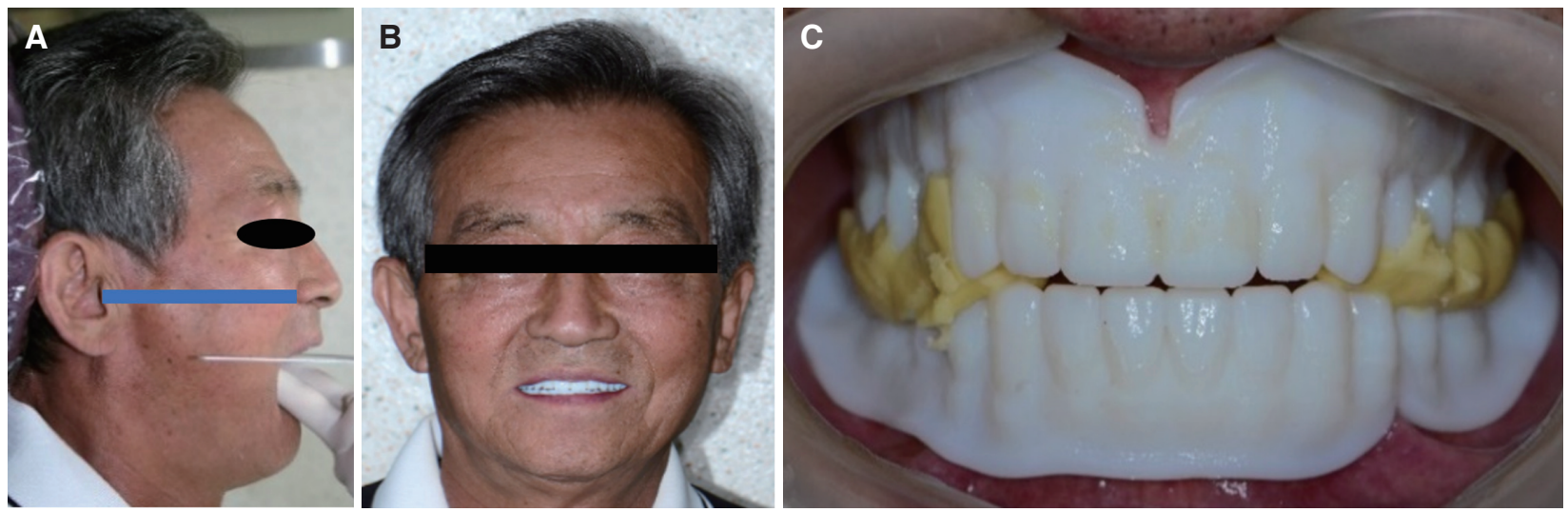

Fig. 4. (A) Checking the occlusal plane of try-in denture at sagittal view, (B) Extra-oral photograph the patient wearing try-in denture, (C) Jaw relation recording on try-in denture.

상, 하악 인상체의 전방부는 다시 구강 내에 위치시 켜 교합 수직 고경을 결정하고 악간 관계를 기록하는데 이용하였다. 교합 수직 고경은 기존에 사용 중이던 임 시 의치를 참고하여 Jaw gauge ${ }^{\circledR}$ (DENTCA)로 결정하 였으며 악간 관계 기록은 EZ-tracer ${ }^{\circledR}$ (DENTCA)을 이 용하였다. 상악 트레이의 바닥에 압력에 의해 표시 가능 한 스티커를 붙이고 하악에는 묘기핀을 위치시켜 결정 된 교합 수직 고경에서 고딕 아치법을 이용하여 중심위 를 표시하였다. 확인된 지점에 round bur로 indentation 을 주어 하악이 기록된 위치로 잘 유도되게 한 후 실리 콘 교합 인기재(Imprint ${ }^{\mathrm{TM}} 4$ Bite, $3 \mathrm{M}$ ESPE, Minnesota, $\mathrm{USA}$ )로 중심위를 채득하였다. 중심위 채득 당시에 환자 의 구각부까지 인기되게 하여 치아 배열에 참고하였다. 상악 전치부의 길이는 Lip ruler ${ }^{\circledR}$ (DENTCA)를 이용하 여 결정하였다(Fig. 3).
이렇게 수집된 인상체와 중심위 기록을 바탕으로 제 작된 try-in denture를 환자의 구강에 삽입하여 교합 평 면, 치축, 수직·수평 피개, 입술 지지도, 교합을 평가하였 다. 교합평면은 전두면에서 환자의 동공을 이은 선과 평 행했으며 시상면에서 비익 이주선과 평행했다. 상악 치 아의 정중선은 안면 정중선과 일치했고 입술 지지도는 만족스러웠다. 하지만 \#27, 37 치아에서 조기 접촉이 있 고 open bite를 보여 교합 조정 후 try-in denture 상에서 다시 악간 관계를 기록하여 최종 의치 수정에 반영하였 다(Fig. 4). 최종 의치는 $2 \mathrm{~mm}$ 의 수직·수평 피개를 가지 며 A2의 teeth shade color, medium pink의 gum shade color로 제작하였다(Fig. 5, 6).

의치 제작에 소요된 총 시간은 전통적인 방법의 경우 가 총 106분(예비 인상 채득이 9분, 최종 인상 채득이 45 분, 악간 관계 기록이 15 분, 납의치 시적이 5 분, 최종 의 


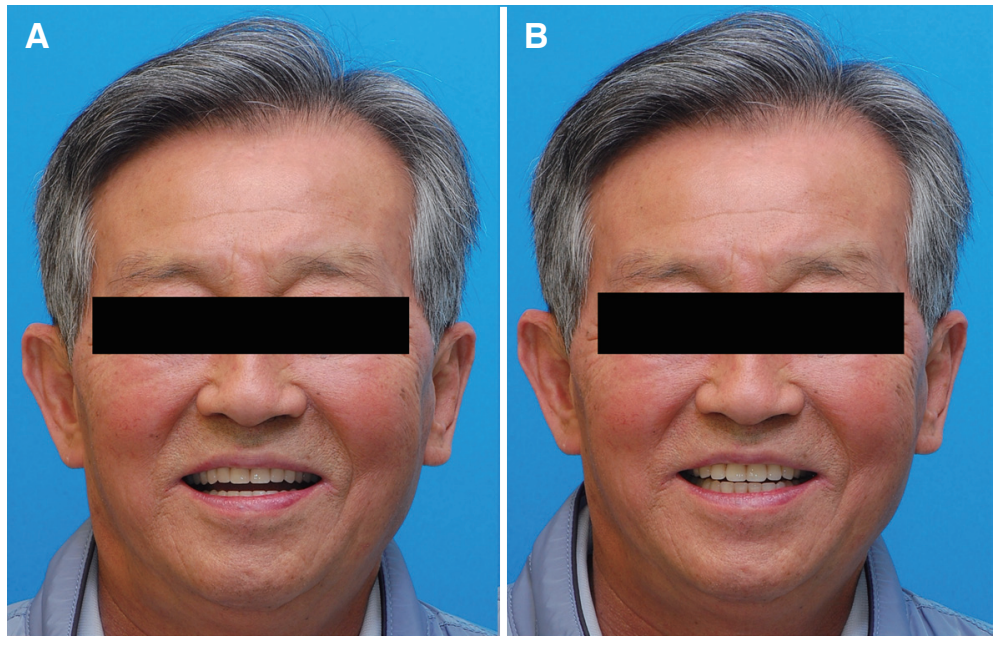

Fig. 5. (A) Extra-oral photograph the patient wearing DENTCA CAD/CAM complete dentures, (B) Extra-oral photograph of the patient wearing conventional complete dentures.
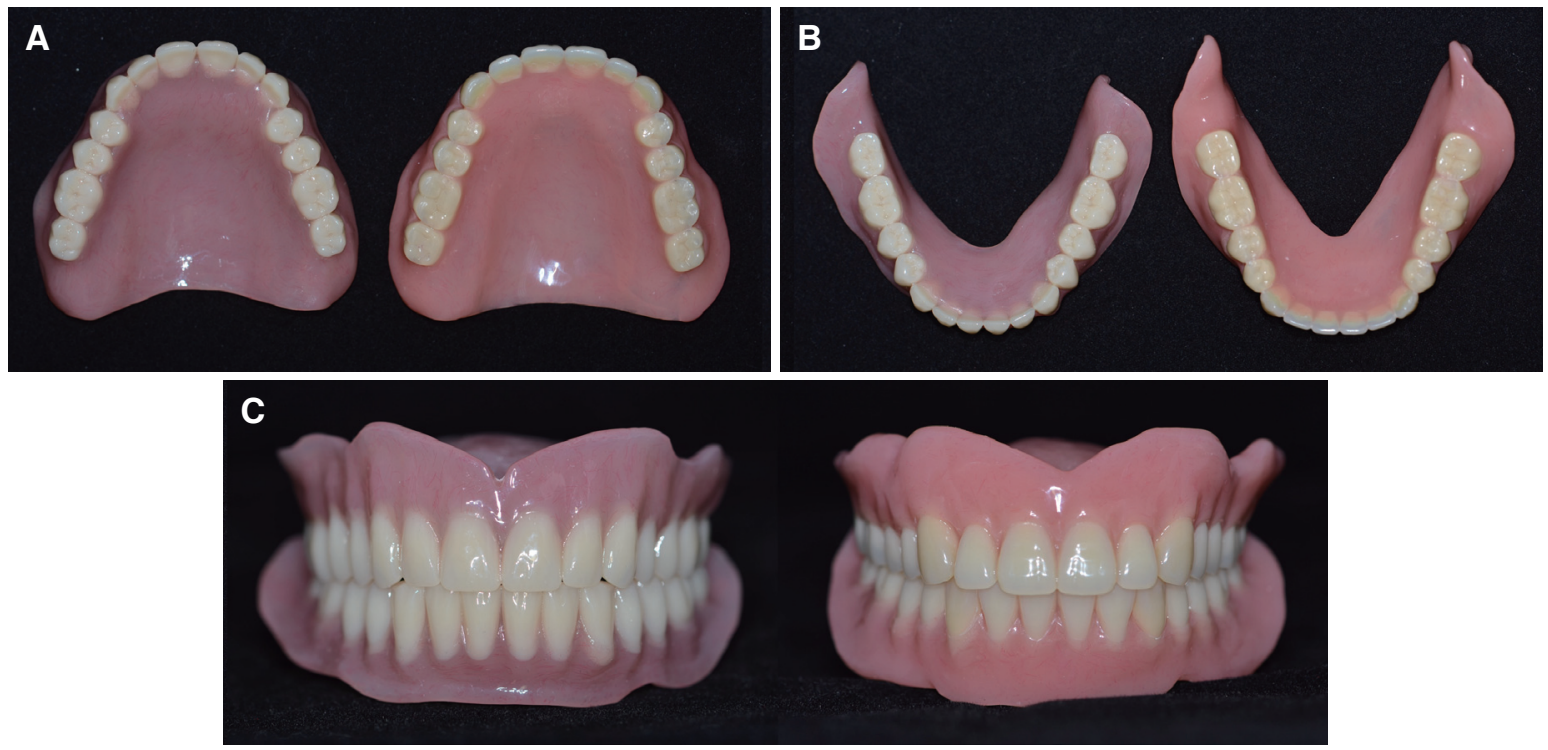

Fig. 6. (A) Occlusal view of maxillary complete dentures (Left: DENTCA CAD/CAM denture, Right: conventional denture), (B) Occlusal view of mandibular complete dentures (Left: DENTCA CAD/CAM denture, Right: conventional denture), (C) Frontal view of maxillary and mandibular complete dentures (Left: DENTCA CAD/CAM dentures, Right: conventional complete dentures).

치 장착이 12 분), DENTCA system을 이용한 경우가 총 104 분(최종인상 채득과 악간관계 기록에 49분, try-in denture 시적 시에 25분, 최종 의치 장착 시에 30 분) 이 었다. 완성된 두 쌍의 의치를 하루씩 번갈아 가며 10 일 간 착용하게 하여 0점부터 100점까지 VAS를 이용한 환 자의 만족도를 조사하였다. 의치에 대해 심미적, 기능
적으로 매우 만족하는 경우는 90점 이상, 대체로 만족 하는 경우는 80 점 이상, 보통인 경우는 70 점, 별로 만족 하지 않는 경우는 60점, 전혀 만족하지 않는 경우는 40 점 이하의 점수를 주도록 하여 주관적인 만족도를 평가 하였다. 환자는 전통적인 방법으로 제작한 의치에 85점, DENTCA system으로 제작한 의치에 75점을 주었다. 


\section{2. 증례 2}

61세의 여자 환자로 치아가 다 흔들려서 뽑고 틀니 를 하고 싶다는 주소로 내원하였으며 고지혈증 외에 의 과적 병력은 없었다. 내원 당시 잔존하는 모든 치아의 동요도가 3 도로 만성 복합성 치주염 진단 하에 잔존치 를 발치하고 상·하악 임시 총의치를 장착하였다. 2 개월 간 임시 의치 사용 후에 전통적인 방법으로 양악 총의치 를 제작하였으며 앞서 보고한 환자와 동일한 방법으로 $\mathrm{CAD} / \mathrm{CAM}$ 의치를 제작하였다.

Try-in denture로 평가시, 전두면에서의 교합평면은
환자의 좌측이 아래로 기울어져 있었으며 시상면에서 의 교합 평면은 구치부가 올라간 상태였다. 치아 정중 선은 환자의 좌측으로 $2 \mathrm{~mm}$ 치우쳐 있었으며 치축도 기울어져 있었다. 구치부에서 조기 접촉되고 전치부는 open bite를 보여 교합 조정 후 다시 악간관계를 기록하 였다. Try-in denture 상에 정중선을 표시하고 교합평면 의 이상은 사진을 첨부하여 최종 의치 제작에 반영하였 다(Fig. 7). 최종 의치는 $2 \mathrm{~mm}$ 의 수직·수평 피개를 가지 며 A3의 teeth shade color, original pink의 gum shade color를 가지도록 제작하였다(Fig. 8).

의치 제작에 소요된 총 시간은 전통적인 방법의 경우
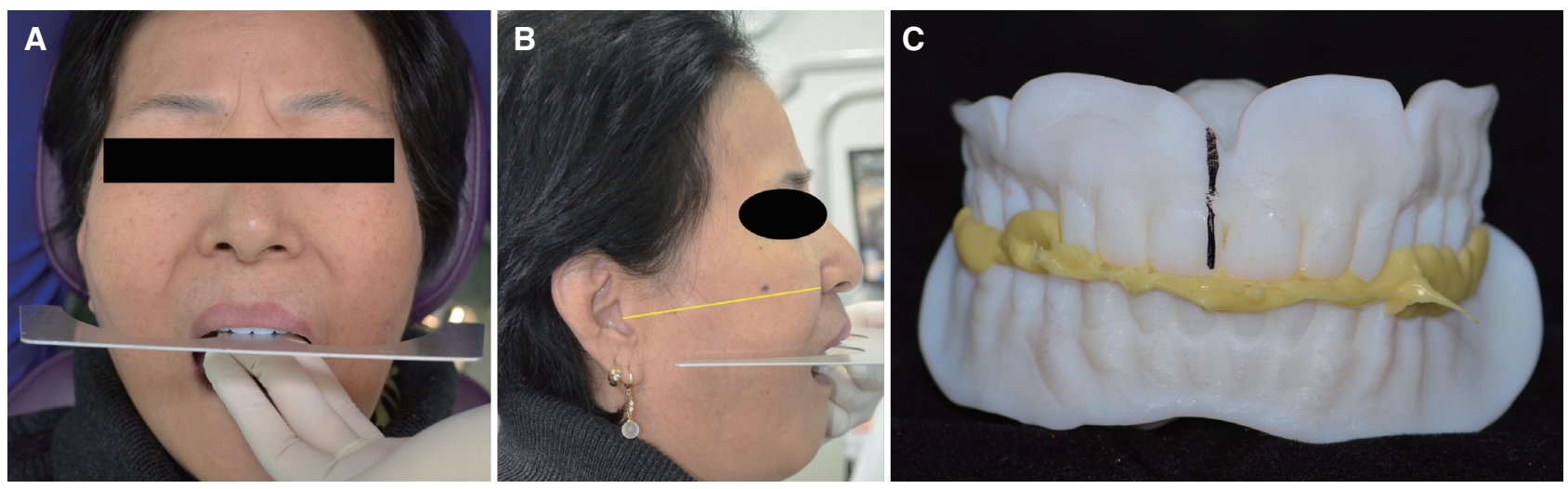

Fig. 7. (A) Checking the occlusal plane of try-in denture at frontal view, (B) Checking the occlusal plane of try-in denture at sagittal view, (C) Jaw relation recording on try-in denture and marking of midline.
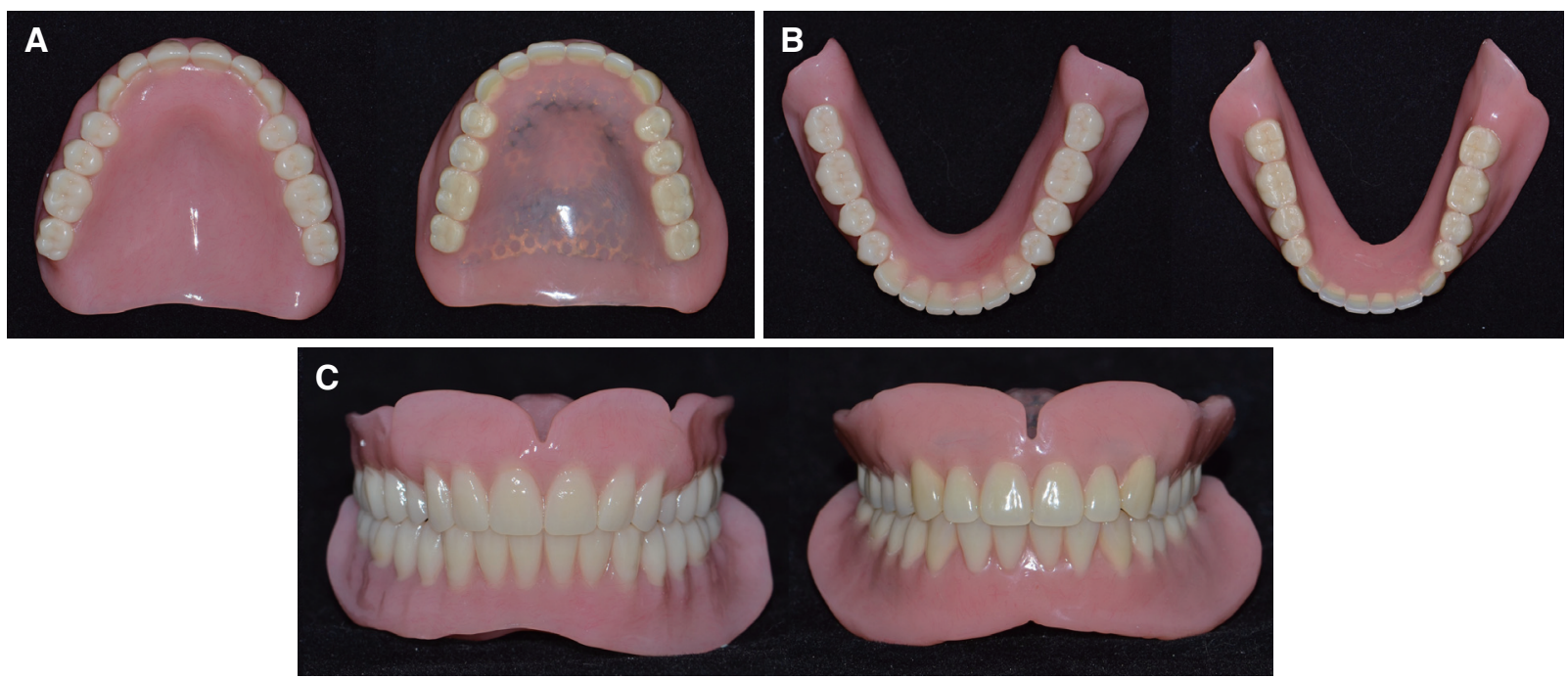

Fig. 8. (A) Occlusal view of maxillary complete dentures (Left: DENTCA CAD/CAM denture, Right: conventional denture), (B) Occlusal view of mandibular complete dentures (Left: DENTCA CAD/CAM denture, Right: conventional denture), (C) Frontal view of maxillary and mandibular complete dentures (Left: DENTCA CAD/CAM dentures, Right: conventional complete dentures). 
가 총 225 분(예비 인상 채득이 10 분, 최종 인상 채득이 130 분, 악간 관계 기록이 45 분, 납의치 시적이 20 분, 최 종 의치 장착이 20 분), DENTCA system을 이용한 경우 가 총 262 분(최종인상 채득과 악간관계 기록에 177 분, try-in denture 시적 시에 45 분, 최종 의치 장착 시에 40 분) 이었다. 전통적인 방법으로 제작한 총의치를 2개월 간 사용한 후, $\mathrm{CAD} / \mathrm{CAM}$ 으로 제작한 총의치를 2개월 간 사용하여 만족도를 조사하였다. 환자는 전통적인 방 법으로 제작한 의치에 90점, DENTCA system으로 제 작한 의치에 80 점을 주었다.

\section{고찰}

$\mathrm{CAD} / \mathrm{CAM}$ system을 이용한 의치의 제작은 환자의 내원 횟수와 진료 시간의 감소, 그에 따른 치료 비용의 감소, 컴퓨터를 이용한 기공 오차의 감소와 저장된 정 보의 재활용 이라는 장점을 가지는 것으로 보고된다. ${ }^{3}$ 본 증례에서 이용한 DENTCA ${ }^{\mathrm{TM}} \mathrm{CAD} / \mathrm{CAM}$ denture 는 한 번의 내원 만으로 의치 제작에 필요한 모든 정보 를 획득할 수 있다고 알려져 있다. 이 시스템은 분리 가 능한 기성 트레이를 사용하여 최종인상을 채득하고 분 리한 인상체의 전방부를 다시 구강 내에 삽입하여 악간 관계를 기록 할 수 있다. 또한 lip ruler를 사용하여 상악 전치부의 길이를 정하고, jaw gauge를 이용하여 교합 수 직 고경을 결정할 수 있으며, 이 정보를 입력하여 컴퓨 터 소프트웨어를 사용해 가상의 상·하악 무치악 치조제 를 형성하고 치아를 배열한다. 제작은 Stereolithograhpy 방법을 사용하여 제작된 try-in denture ${ }^{7}$ 를 환자에게 시 적하여 교합평면, 치축, 수직고경, 입술지지도 등을 평가 하고 이것을 수정하여 매몰, 중합하는 방법으로 최종 의 치를 제작한다.

본 증례에서는 DENTCA system과 전통적인 방법을 동 시에 이용하여 상 하악 총의치를 제작하고 각각의 환자에 게서 진료시간, 내원 횟수, 환자만족도를 기록하였다.

Case 1의 진료시간은 전통적인 방법이 106분, DENTCA system이 104분 소요되었으며, 환자만족도는 전통적 인 방법이 85점, DENTCA system이 75점을 기록하 였다. Case 2의 진료시간은 전통적인 방법이 225분, DENTCA system이 262분 소요되었고 환자만족도는 전통적인 방법이 90점, DENTCA system이 80점을 기 록하였다. 내원 횟수는 두 증례 모두에서 전통적인 방법 이 5회, DENTCA system을 이용한 방법이 3회였다.
전통적인 방법의 진료 시간이 훨씬 더 길 것이라 는 예상과 달리 두 방법의 진료 시간이 비슷하거나 DENTCA system에서 길게 측정 되었는데 이는 다음 과 같은 원인 때문이라고 생각된다. 첫째, 기존의 의치 제작 방법은 치과의사가 수년간 익숙하게 사용해오던 과정이기 때문에 숙달되어 빨리 진행할 수 있었다. 둘 째, DENTCA system은 4개로 제한된 기성 트레이를 제공하므로 이것을 환자의 잔존 무치악에 맞추는 과정 이 오래 걸렸다. 셋째, DENTCA system의 중심위 채득 시 인상체 후방 부위의 접촉이 있어 open bite의 try-in denture가 제작되었고 이를 수정하는 교합 조정 과정에 시간 소요가 많았다. 특히 환자의 수직 교합 고경이 낮 았던 두 번째 증례의 경우에는 악간 관계 채득 시 접촉 되는 트레이를 조정하는데 상당한 시간이 소요되어 전 통적인 방법보다 진료 시간이 증가하였다. 전체적인 진 료시간을 줄이기 위해서는 개개인의 환자의 무치악에 맞도록 변경 가능한 트레이나, 다양한 형태와 크기를 갖 는 기성 트레이의 개발이 필요할 것으로 보인다.

내원 횟수는 두 케이스 모두 전통적인 방법으로는 5회 의 내원, DENTCA system을 이용한 경우에는 3 회의 내 원이 필요했다. DENTCA system이 2번의 내원 만으로 도 만족스러운 의치 제작이 가능하다고 알려져 있던 것 과는 다르게 첫날 내원 시에 교합 평면과 입술지지도에 대한 정보를 기록할 수 없고 정확한 악간 관계의 확인을 위해서 try-in denture의 시적은 필수적인 단계로 보인 다. 하지만 앞서 기술한 전통적인 방법의 총의치의 제작 은 총 5 번의 내원을 필요로 한다. 만약 악간 관계 채득에 오류가 있거나 치아배열이 만족스럽지 않은 경우에는 납의치 시적을 한 번 더 시행하게 되고 환자가 무치악 상태로 있는 기간 혹은 임시 의치를 사용하는 기간은 더 길어진다. 따라서 대개 의치 제작 완성까지는 4 주에서 5 주의 기간을 필요로 한다. 하지만 CAD/CAM system을 이용할 경우, try-in denture 시적 과정을 거쳐도 3 번의 내원 만으로 의치 제작이 가능하고 컴퓨터로 작업이 이 루어지므로 제작 기간을 2주 이내로 단축시킬 수 있을 것이다.

첫 번째 증례에서 DENTCA 의치에 대한 환자의 만 족도가 감소한 주된 원인은 의치의 거친 내면 때문이 었고 이것은 3 dimensional (3D) printing의 결과로 보 인다. 3D printing으로 제품을 만드는 방법은 additive manufacturing (적층가공)과 subtractive manufacturing (절삭가공)이 있다. ${ }^{3}$ Additive manufacturing은 디지털 
파일의 이미지를 이용하여 선택된 재료를 연속적으로 쌓는 방식이며 subtractive manufacturing은 이미지를 이용하여 재료를 cutting 하거나 milling 하여 완성품을 만드는 방법을 말한다. 이 중 additive manufacturing을 이용하면 복잡한 형태를 만들 수 있지만 표면이 매끄럽 지 못하다는 단점이 있다. DENTCA 의치는 레이저를 이용하여 광경화성 액체 수지를 선택적으로 중합시키는 stereolithography (SLA) 방법으로 try-in denture를 제 작한다. 따라서 DENTCA 의치의 거친 내면은 현재 $3 \mathrm{D}$ 프린팅 기술이 갖는 한계점으로 볼 수 있다.

두 번째 증례에서 DENTCA 의치에 대한 환자 의 만족도가 감소한 주된 원인은 유지력 부족이었다. Jacobson (1983)은 의치의 유지력에 영향을 주는 요인 들로 adhesion, cohesion, interfacial surface tension, gravity, intimate tissue contact, border seal, atmospheric pressure, neuromuscular control을 언급한 바 있다. ${ }^{9}$ DENTCA 의치는 프린팅한 try-in denture를 최종 의치 로 바꾸는 과정 중에 여전히 레진의 중합 수축이 발생하 므로 intimate tissue contact을 완벽하게 얻을 수 없을 것 이다. 또한 변연 형성 과정 중에 조직에 약한 압력을 가 하는 것이 의치변연의 positive contact에 도움이 되나 모델링 컴파운드를 사용하지 않은 변연 형성 과정이 의 치의 유지력을 감소시켰을 것으로 판단된다.

제작된 최종 의치를 살펴보면, 전통적인 방법으로 제 작된 의치의 변연 길이가 더 길고 두꺼웠으며 견치 간의 폭경이 더 크게 관찰되었다. 변연의 길이와 두께의 차이 는, 전통적인 방법에서 환자의 무치악에 맞는 개인 트 레이를 제작하여 변연 형성을 수회에 나눠서 했기 때문 이라 생각되며 견치 간 폭경의 차이는, 현재 DENTCA system이 서양인의 악궁과 치열에 맞추어진 치아 배열을 하여 생긴 것으로 추측해 볼 수 있다. 두 환자 모두 전체 적인 만족도는 전통적인 방법에서 조금 더 높게 나타났 으나 심미적인 만족도는 DENTCA system 의치에서 높 게 나타났는데 이는 teeth shade뿐만 아니라 gum shade 를 선택할 수 있는 system이 갖는 장점이라 생각된다.

\section{결론}

두 환자에서 전통적인 방법과 DENTCA system을 이 용하여 상·하악 총의치를 제작해 보았다. DENTCA 의 치는 3 번의 내원으로 기능적, 심미적으로 만족할만한 의치 제작이 가능했다. $3 \mathrm{D}$ 프린팅 기술의 발전과 함께
현재 DENTCA system이 갖고 있는 한계점(교합평면과 입술지지도에 대한 정보 기록, 인상채득 방법 등)을 개 선한다면 2번의 내원 만으로도 더욱 만족도 높은 의치 제작이 가능할 것이다.

\section{ORCID}

Mi-Jin Kim http://orcid.org/0000-0002-3076-6950

\section{References}

1. Douglass CW, Shih A, Ostry L. Will there be a need for complete dentures in the United States in 2020? J Prosthet Dent 2002; 87:5-8.

2. Zarb GA, Bolender CL. Prosthodontic treatment for edentulous patients. 12th ed. St. Louis; Mosby; 2004. p. 190-207.

3. Bidra AS, Tylor TD, Agar JR. Computer-aided technology for fabricating complete dentures: systematic review of historical background, current status, and future perspectives. J Prosthet Dent 2013;109: 361-6.

4. Murray MD, Darvell BW. The evolution of the complete denture base. Theories of complete denture retention-a riview. Part 1. Aust Dent J 1993;38: 216-9.

5. Kanazawa M, Inokoshi M, Minakuchi S, Ohbayashi N. Trial of a CAD/CAM system for fabricating complete dentures. Dent Mater J 2011;30:93-6.

6. Dankwort CW, Weidlich R, Guenther B, Blaurock JE. Engineer's CAx education-it's not only CAD. Computer-Aided Design 2004;36:1439-50.

7. Kattadiyil MT, Goodacre CJ, Baba NZ. CAD/ CAM complete dentures: a review of two commercial fabrication systems. J Calif Dent Assoc 2013; 41:407-16.

8. Park JH, Cho IH, Shin SY, Choi YS. The treatment of an edentulous patient with DENTCATM CAD/ CAM denture. J Korean Acad Prosthodont 2015; 53:19-25.

9. Jacobson TE, Krol AJ. A contemporary review of the factors involved in complete denture retention, stability, and support. Part I: retention. J Prosthet Dent 1983;49:5-15. 


\section{$\mathrm{CAD} / \mathrm{CAM}$ system과 전통적인 방법을 이용한 총의치 동시 제작 증례}

\section{김미진, 김강호, 여동헌*}

삼육치과병원 치과보철과

Computer-aided technology는 최근 치과 치료의 흐름이다. DENTCA ${ }^{\mathrm{TM}} \mathrm{CAD} / \mathrm{CAM}$ denture (DENTCA Inc.)는 상용 화된 computer-aided design/computer-aided manufacturing (CAD/CAM) 의치 시스템 중 하나로, 한 번의 내원을 통 해 의치 제작에 필요한 환자의 모든 정보를 획득하여, 이 정보를 컴퓨터에 저장하고 $3 \mathrm{D}$ 프린팅을 통해 두 번째 내원 시 에 의치 장착을 목표로 한다. 현재까지 여러 증례들은 총의치 제작에 대한 CAD/CAM system의 임상적 적용을 시험해 보았다. 본 증례는 두 명의 환자에서 DENTCA system을 이용한 의치와 전통적인 방법을 이용한 의치를 동시에 제작 하여 DENTCA system의 효용성과 한계점을 고찰하였다.

(구강회복응용과학지 2016;32(2):141-8)

주요어: $\mathrm{CAD} / \mathrm{CAM}$; 총의치

*교신저자: 여동헌

(02500) 서울특별시 동대문구 망우로 82 삼육치과병원 치과보철과

Tel: 02-3407-2822 | Fax: 02-3407-2874 | E-mail: polacca7@gmail.com

접수일: 2016년 5월 20일 | 수정일: 2016년 6월 13일 | 채택일: 2016년 6월 14일 